\title{
Production of reducing sugars by Trichoderma sp. KUPM0001 during solid substrate fermentation of sago starch processing waste hampas
}

\begin{abstract}
Trichoderma sp. KUPM0001 showed good growth during solid substrate fermentation (SSF)of sagopith residue known as hampas, supplemented with $10 \%$ (v/w) of mineral salts solution containing $0.5 \%(\mathrm{w} / \mathrm{v})(83.3 \mathrm{mM})$ urea as nitrogen source and an initial moisture content of $80 \%(\mathrm{v} / \mathrm{w})$. Mycelium suspension of $10 \%(\mathrm{v} / \mathrm{w})$ density was used as initial inoculum and SSF was carried out at $25 \pm 2^{\circ} \mathrm{C}$ in static condition over a period of $120 \mathrm{~h}$. The parameters optimized include the initial moisture content of the substrate, mineral salts solution, urea concentration, inoculum density, incubation temperature and incubation time. Without optimized condition, the maximum reducing sugar obtained was $24 \mathrm{mg} \mathrm{mL}^{-1}$ compared to $46 \mathrm{mg} \mathrm{mL}^{-1}$ substrate during optimized SSF after $96 \mathrm{~h}$ incubation. The optimum parameters obtained were $80 \%(\mathrm{v} / \mathrm{w})$ of initial moisture; $10 \%(\mathrm{v} / \mathrm{w})$ of inoculums size; $1.0 \%$ of urea in $20 \%(\mathrm{w} / \mathrm{v})$ of mineral solution and incubated at $30 \pm 2^{\circ} \mathrm{C}$. The enzyme activities using optimized condition gave maximum Ŭ-amylase, glucoamylase, carboxymethyl cellulase, filter paperase and 6 -glucosidase of $3.19,2.22,1.66,1.11$ and $1.48 \mathrm{U} \mathrm{mL}^{-1}$, respectively.
\end{abstract}

Keyword: Trichoderma sp. KUPM0001; Optimization; Solid substrate fermentation 